\title{
Physico-Chemical and Microbiological Assessment of Organic Pollution in Plain Salty Lakes from Protected Regions
}

\section{Veronica Lazar ${ }^{1,2,3}$, Carmen Curutiu1,2, Ditu Lia-Mara1,2, Alina Holban1,2, Irina Gheorghe1,2, Florica Marinescu, Mihaela Ilie ${ }^{4}$, Ecaterina Marcu, ${ }^{4}$ Alex Ivanov, Dumitru Dobre ${ }^{3}$, Mariana Carmen Chifiriuc1,2}

\author{
${ }^{1}$ Botany-Microbiology Department, Faculty of Biology, University of Bucharest, Bucharest, Romania \\ ${ }^{2}$ The Research Institute of the University of Bucharest, Bucharest, Romania \\ ${ }^{3}$ Maximilian Association, Buzau, Romania \\ ${ }^{4}$ The National Institute for Research and Development in Environmental Protection-INCDPM, Bucharest, Romania \\ Email: veronica.lazar2009@gmail.com,carmeniordache78@yahoo.com, alina_m_h@yahoo.com,iryna_84@yahoo.com, \\ florinamar@yahoo.com,belona2005@yahoo.com,carmen_balotescu@yahoo.com
}

How to cite this paper: Lazar, V., Curutiu, C., Lia-Mara, D., Holban, A., Gheorghe, I., Marinescu, F., Ilie, M., Marcu, E., Ivanov, A., Dobre, D. and Chifiriuc, M.C. (2017) Physico-Chemical and Microbiological Assessment of Organic Pollution in Plain Salty Lakes from Protected Regions. Journal of Environmental Protection, 8, 1474-1489. https://doi.org/10.4236/jep.2017.812091

Received: October 11, 2017

Accepted: November 24, 2017

Published: November 27, 2017

Copyright ( 2017 by authors and Scientific Research Publishing Inc. This work is licensed under the Creative Commons Attribution International License (CC BY 4.0).

http://creativecommons.org/licenses/by/4.0/ (c) (i) Open Access

\begin{abstract}
One of the most important goals of EU nature and water framework directives is to ensure healthy aquatic ecosystems by the protection of the most valuable species and habitats form the Natura 2000 network, while at the same time ensuring a balance between water/nature protection and the sustainable use of nature's natural resources. The purpose of this study was to evaluate the physico-chemical and microbiological characteristics of four Romanian salty plain lakes included in Natura 2000 Network, in order to assess the degree of organic pollution and to generate the knowledge required for the design and implementation of appropriate measures for maintaining the balance between the water protection and the sustainable use of these protected ecosystems. The water and sediment sampling was performed in two consecutive years (2015 and 2016), in September and the following standard parameters have been determined: $\mathrm{pH}$, chemical oxygen consumption (COC), the degree of trophicity and salinity of the environment, metals content, microbiological indicators and microbial physiological groups involved in nutrient cycling. The $\mathrm{pH}$ ranged from 7.56 to 8.93 , close or above the upper normal limit of 8.5, being correlated with a high salinity characteristic of chlorinated, sulphated, high sodium and magnesium content waters. Despite the similar values recorded for the physico-chemical parameters in the two consecutive years suggesting a certain degree of stability of the investigated aquatic ecosystems, the COC values indicate a high degree of hypertrophy, which could be attributed
\end{abstract}


to the reduced surface area, ecological pisciculture and agriculture input. The microbiological parameters revealed the existence of both recent and chronic fecal pollution source. The high hypertrophy degree could represent a positive premise for the high productivity of the investigated ecosystems, but also an alarm signal for excessive organic pollution, with the risk of redox potential decrease which can affect the fish and other life forms. Consequently, it is necessary to identify the sources of pollution and implement the appropriate measures to minimize the negative impact of organic contamination on the status of the respective ecosystems (water quality, biotic components) in order to maintain the health of both ecosystems and the surrounding human communities, allowing at the same time a sustainable use of the local resources.

\section{Keywords}

Salty Lakes, Physico-Chemical Characteristics, Microbiological Parameters, Protected Ecosystems, Hypertrophy

\section{Introduction}

The protection of Europe's most valuable species and habitats form the Natura 2000 network is regulated by many EU incentives, such as "Birds", "Habitats" and "Water Framework" Directives, EU's biodiversity policy etc., which aim to provide some of the main tools required for bringing protected species and habitats into a favorable conservation status (to prevent the deterioration of any status), thus ensuring both healthy aquatic ecosystems (good ecological potential and good chemical status in artificial and heavily modified water bodies) and a balance between water/nature protection and the sustainable use of nature's natural resources. In order to achieve these goals, measures to progressively reduce pollution from priority substances and ceasing or phasing out emissions, discharges and losses of priority hazardous substances need to be implemented [1] [2]. Lake waters pollution can be physical (soil particles eroded from landscape or washed by flowing water, heat discharged from an industrial source or from runoff from hot surfaces in warm weather or cooling waters), chemical (including major inorganic elements dissolved from soil and rocks or from plants, as well as organic compounds from decaying materials and discharged from human-made urban, agricultural or industrial environments) and biological (non-native plants and animals, overabundance or selective growth of some native species etc.) [3] [4].

The aquatic environments, including the river and lake waters, through their physico-chemical and microbiological features, are essential for the biogeochemical cycles, and consequently for the productivity and evolution of the respective ecosystems [5] [6]. The microorganisms remineralize the organic matter to carbon dioxide, water, and various inorganic salts both in aquatic and terrestrial ecosystems. Many substances, such as lignin, cellulose, chitin, pectin, agar, 
hydrocarbons, phenols, and other organic chemicals, are degraded by microbial action. The rate of decomposition of organic compounds depends upon their chemical structure and complexity and upon environmental conditions. Mineralization of organic substances begins in the mass of water and continues with maximum intensity at the sediments surface where bacteria develop multispecific populations embedded in biofilms in which metabolic cooperation relationships are established [7]. Aquatic sediments represent a distinct ecological zone characterized by a low redox potential and a microstratification of physico-chemical factors that facilitate the occurrence of specific ecological niches, favoring the excessive growth of heterotrophic bacteria, and particularly of microaerophilic and strictly anaerobic species.

The high diversity of the aquatic microbiota is sustained by the relatively large input of organic substances, resulted from local flora and fauna, but also from the contamination with soil microbiota and with wastewaters discharged from the riparian human communities [1] [8] [9] [10]. Organic pollutants can bring about a change in the physico-chemical characteristics of water and also cause changes in the biotic components of the ecosystem, resulting in loss of biodiversity. The presence of large amounts of organic substances, either dissolved or particulate, as well as of complex ions favors the selection of certain microbial groups, whose specific metabolic activities and physiology could underly both qualitative and quantitative changes, depending on the variation of environmental conditions (redox potential, temperature etc.) [11]. Both dissolved and sedimentary sources of pollution affect living organisms and produce adverse effects on fish [9]. Although the use of chemical fertilizers, pesticides, herbicides and other agricultural inputs derived from fossil fuels have increased agricultural production, there are growing awareness and concern over their adverse effects on indigenous microbiota and consequently, on the environmental quality [12] [13]. Thus, the acquatic indigenous microbiota has a high potential to provide biomarkers for early warning of environmental changes, since microbiological responses are rapid and can be detected within hours or days.

The purpose of this study was to evaluate and correlate the physico-chemical and microbiological characteristics of four salty plain lakes located in the protected sites ROSCI0005 and ROSPA0004 of the Natura 2000 Network, in order to assess the degree of organic pollution and generate the knowledge required for the design and implementation of appropriate measures for maintaining a normal, balanced long-term state and for allowing a sustainable and environmentally friendly exploitation of these ecosystems.

\section{Materials and Methods}

The water and sediments sampling was performed once, during the month of September, for two consecutive years, i.e. in 2015 and 2016, according to SR ISO 5667-2/2007, Part 2: General guide for sampling techniques for physico-chemical analysis (including PhACs detection and quantification) and SR EN ISO 19,458: 
2007, Water quality. Sampling for microbiological analysis. The sampling points have been represented by four lakes circumscribed to a plain area of approx. 6000 ha of water and 2000 ha of land with various uses from Buzau and Braila counties, namely: ROSCI0005 Balta Alba-Amara-Lacul Sarat Caineni-Jirlau, ROSPA0004 Balta Alba-Amara-Jirlau and the area of reservations 2.271-Balta Alba, 2.272-Balta Amara, 2.260-Lacul Jirlau-Trup Visani (Figure 1). The collection of samples was performed under base flow (dry-weather) conditions at regular time intervals (in the morning time, between 9 and 11), the air temperature ranging from $20^{\circ} \mathrm{C}$ to $25^{\circ} \mathrm{C}$. Dates of sample collection were selected, on the basis of weather forecasts, in order to have the same hydrological and wind conditions. The water sampling was performed from $0.5 \mathrm{~m}$ depth by aid of a Sieburth device, from a sampling point located at a distance of $4-5 \mathrm{~m}$ from the lake shore. The sediments were collected by either a bottom hole sampler or dredge equipment.

The samples were harvested in sterile containers and transported in refrigerated bags, then analyzed by physico-chemical and microbiological standard

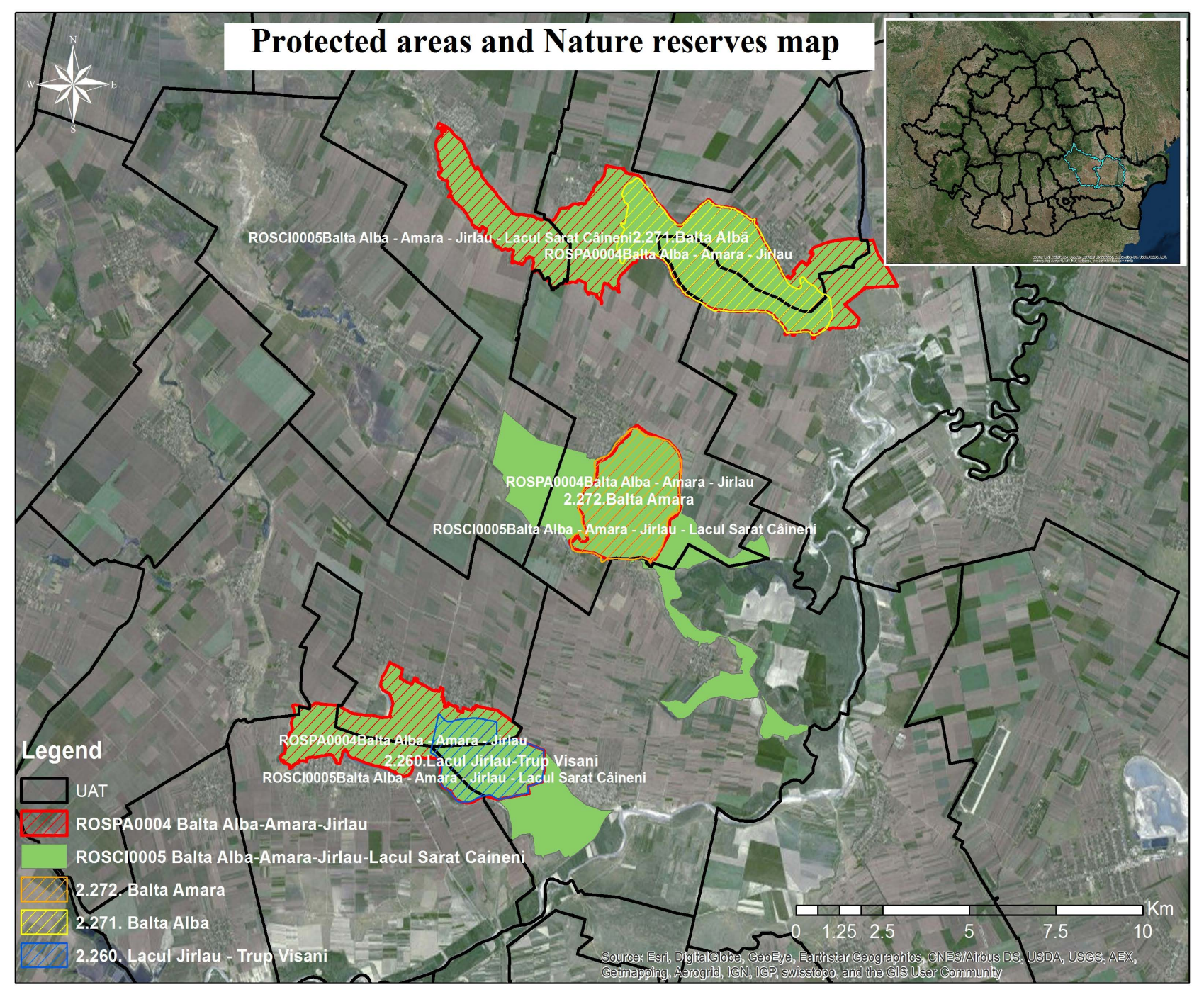

Figure 1. Representation of the geographical location of the sampled lakes. 
methods in maximum $24 \mathrm{~h}$ from sampling. The analyzed physico-chemical parameters were: the $\mathrm{pH}$ of the samples, the chemical oxygen consumption, the degree of trophicity and salinity of the environment, as well as the content in metals, including heavy metals. The microbiological analyses consisted in the assessment of the water quality bacteriological indicators, i.e.: the number of total coliforms and faecal coliforms, enterococci and mesothermic heterotrophic bacteria determined by total viable count method $(\mathrm{CFU} / \mathrm{mL})$, as well as of the most probable number of microorganisms belonging to physiological groups involved in the biodegradation of organic matter and in the cycle of the main biogenic elements (carbon, nitrogen and sulfur) (proteolytic, ammonifying, nitrifying, denitrifying and sulphate reducing bacteria) determined by the McCrady multiple tubes method [12] [14] [15]. The obtained results for water quality bacteriological indicators were reported in the New Classification System of bacteriological indicators for surface water quality proposed by UE (New UE-Expert Proposal), allowing the classification of water in five quality classes (Table 1) [16].

\section{Results and Discussions}

\subsection{General Characteristics of the Plain Lakes and Surrounding Areas}

The analyzed four lakes are located in lowland areas, in the Eastern sector of the Romanian Plain, north of the Călmăţui River (in Râmnicu-Valcea and Baragan Plain), being part of the Buzău-Ialomița hydrographic area, with an approx. 6000 ha of water and 2000 ha of surrounding lands with various uses, with strong winds, low rainfall, with periods of heat and rain in the summer, with a strong soil erosion effect. The lake Balta Alba (Buzau) has an area of 1200 - 1300 ha. An ecological pit lies in its vicinity, as well as the Pell Amar Cosmetics factory (raising a risk of waste water (possibly containing industrial chemical waste like mineral salts, solvents etc.) discharge in the lake. The lake is also used for recreational purposes. The common reed and the fir three are the most common vegetation on the banks of the lake.

Table 1. Limit values of bacteriological parameters for surface water quality [16].

\begin{tabular}{ccccccc}
\hline \multicolumn{2}{c}{ Microbiological assesment } & \multicolumn{4}{c}{ Classification system of bacteriological parameters for quality surface water } \\
\hline Parameter & Faecal pollution & $\begin{array}{c}\text { I } \\
\text { low }\end{array}$ & $\begin{array}{c}\text { II } \\
\text { moderate }\end{array}$ & $\begin{array}{c}\text { III } \\
\text { critical }\end{array}$ & $\begin{array}{c}\text { IV } \\
\text { strong }\end{array}$ & $\begin{array}{c}\text { V } \\
\text { excessive }\end{array}$ \\
\hline Total coliforms $/ 100 \mathrm{ml}$ & $<500$ & $>500-10,000$ & $10.000-100,000$ & $100.000-1,000,000$ & $>1,000,000$ \\
Faecal coliforms $/ 100 \mathrm{ml}$ & $<100$ & $>100-1000$ & $1000-10,000$ & $10.000-100,000$ & $>100,000$ \\
Intestinal enterococci/ $100 \mathrm{ml}$ & $<50$ & $>50-100$ & $100-1000$ & $1.000-10,000$ & $>10,000$ & IV \\
Parameter $\quad$ Organic pollution & I & II & moderate & critical & strong & excessive \\
Heterotrophic Plate Count $22^{\circ} \mathrm{C}$ & $<500$ & $>500-10,000$ & $10.000-100,000$ & $100.000-750,000$ & $>750,000$ \\
\hline
\end{tabular}

${ }^{\star} \mathrm{CFU} / \mathrm{ml}=$ colony forming units/Ml. 
The Lake Balta Amara (Buzau) has 800 ha and is located near the village of Amara, being thus surrounded by agricultural areas cultivated with grain, sunflower. It is used for pisciculture of the juvenile fish, respectively ecological Wild Common Carp and Prussian Carp. The Salty Lake Câineni (Braila) has an area of 96 ha and was previously used as a spa resort, being one of the best local sources of sapropelic mud, which is extracted here and used even in the biggest spa centers from the Romanian seaside (e.g., Techirghiol, Eforie). The lake has a very high natural salinity (probably augmented by the intake of chemical fertilizers). The Jirlau (Braila) lake has an area of 1000 ha and is surrounded by common reed and agricultural areas. In 1970, the Buzau River naturally changed its course, the phenomenon adversely affecting the water level in the lakes from the area, especially Amara and Câineni. At the same time, the construction of the Siriu Dam made the Buzau River only rarely coming out of the riverbed flooding the riparian areas.

The studied lakes host major migratory bird populations, belonging to approx. 60 species protected at European level, represented by many pairs nesting regularly in the wet habitats of the site [17]. The investigated lakes represent a feeding, orientation or stationary place for these birds, which justifies the enclosure of these areas on the "Natura 2000" sites list, with the codes ROSCI0005 [18] and ROSPA0004 [19]. The birds are moving along the Central European main aisle (this stretches from the cold and wetlands of the northern European countries and passes through the coastal lands of the Botnic gulf and Finic gulf, from the Baltic countries and also through the Poland Mazovian plain, besides the arch of the Poland, Ukrainian and Romanian Carpathians, cross the Prut and Siret rivers, meeting the Danube Delta, and after passing the Turkish straits, pass by the mountains of Anatolia and continue on the southern shore of Turkey, Liban and Israel to the Nile Delta, climbing the river to the depth of Africa, in the area of Tanganica Lake. The ROSCI0005 site is of great ecological interest, hosting protected plant species (Salicornia sp.), batracians and mammals. The ROSPA0004 site hosts 134 bird species, some of them with great avifauna value, being included in Annex 1 of the Council of Europe Directive 79/409 EEC/2 April 1979 regarding the conservation of wild birds; Convention No. 6/1998 also mentions other protected species. Among species of nesting birds listed on the Red List of Endangered Species (IUCN Red List), present in the analyzed area, we can mention: the dalmatian pelican (Pelecanuscrispus), ferruginous duck (Anythianyroca), Eastern imperial eagle (Aquila heliaca), kestrel (Falco naumanni), the corncrake (Crex crex) [20].

\section{Physico-Chemical Characteristics of the Analyzed Plain Lakes}

The Ca: $\mathrm{Mg}$ ratio of the analyzed lakes was outside the acceptable limits for Balta Alba and Jirlau lakes, indicating a much higher than normal amount of $\mathrm{Mg}$ ions. However, previous assays performed for more than one decade have demonstrated that this is a constant feature of the investigated ecosystems. The potential sources for high $\mathrm{Mg}$ concentrations could be the anthropogenic activities, 
organic and chemical fertilizers or the industrial pollution [21] [22] [23] [24]. The higher amount of $\mathrm{Mg}$ ions can cause disturbances in the physiology of plants and animals, and particularly in the development of phytoplankton and could explain the sweetener taste of the fish meat. The negative effects can be countered by treating the water with $\mathrm{CaCO}_{3}$ or $\mathrm{CaO}$.

The results of the physico-chemical determinations performed for two consecutive years during September (Table 2) were interpreted according to Ord. 161/2006, and indicated expected values. The water $\mathrm{pH}$ was close or even above the upper acceptable limit (6.5 - 8.5), being correlated with the increased salinity of these lakes (indicated by the high values of chlorine and sulphate ions). The chemical oxygen consumption (COC) parameter is preferred to the biochemical

Table 2. The results of physico-chemical determinations for the water samples analyzed in 2015 and 2016.

\begin{tabular}{|c|c|c|c|c|c|c|c|c|c|}
\hline \multirow{2}{*}{ Parameters } & \multirow{2}{*}{ Unit } & \multicolumn{2}{|c|}{ Lake Balta Alba } & \multicolumn{2}{|c|}{ Lake Amara } & \multicolumn{2}{|c|}{ Lake Caineni } & \multicolumn{2}{|c|}{ Lake Jirlau } \\
\hline & & 2015 & 2016 & 2015 & 2016 & 2015 & 2016 & 2015 & 2016 \\
\hline $\mathrm{pH}$ & $\mathrm{pH}$ unit & 8.93 & 8.72 & 7.72 & 7.56 & 8.15 & 7.82 & 8.81 & 8.82 \\
\hline CCO-Mn & $\mathrm{mg} \mathrm{O}_{2} / \mathrm{L}$ & 17.8 & 27.98 & 22.45 & 23.19 & 51.87 & 42.37 & 33.29 & 44.77 \\
\hline $\mathrm{N}-\mathrm{NO}_{2}^{-}$ & $\mathrm{mg} / \mathrm{L}$ & 0.7309 & 0.1016 & 0.0075 & 0.0553 & 0.0105 & 0.0086 & 0.0239 & 0.0897 \\
\hline $\mathrm{N}-\mathrm{NO}_{3}^{-}$ & $\mathrm{mg} / \mathrm{L}$ & 0.0831 & 0.0329 & 0.3844 & 0.0688 & 0.5272 & 0.0857 & 0.1038 & 0.5351 \\
\hline $\mathrm{N}-\mathrm{NH}^{4+}$ & $\mathrm{mg} / \mathrm{L}$ & 0.3435 & 1.6084 & 0.9043 & 0.5217 & 1.5304 & 0.6087 & 1.613 & 0.413 \\
\hline $\mathrm{Nt}$ & $\mathrm{mg} / \mathrm{L}$ & 2.972 & 4.4 & 3.264 & 3.02 & 5.012 & 4.17 & 4.429 & 3.3 \\
\hline P- $\mathbf{P O}_{4}^{3-}$ & $\mathrm{mg} / \mathrm{L}$ & 0.2026 & 0.1936 & 0.1148 & 0.3272 & 0.0946 & 0.02 & 0.0608 & 0.0134 \\
\hline $\mathrm{Pt}$ & $\mathrm{mg} / \mathrm{L}$ & 0.3131 & 0.4407 & 0.2674 & 0.6186 & 0.45 & 0.1747 & 0.359 & 0.2367 \\
\hline $\mathrm{SO}_{4}^{2-}$ & $\mathrm{mg} / \mathrm{L}$ & 1634.78 & 1800 & 2091.3 & 1400 & 12456.5 & 8750 & 1026 & 765.22 \\
\hline $\mathrm{Cl}^{-}$ & $\mathrm{mg} / \mathrm{L}$ & 5211.59 & 4467.2 & 3190.77 & 2127.24 & 14074.8 & $11,061.7$ & 531.8 & 567.26 \\
\hline Conductivity & $\mathrm{ms} / \mathrm{cm}$ & 18.42 & 16.32 & 12.65 & 8.81 & 47.2 & 36.6 & 4.77 & 4.34 \\
\hline Fixed residue & $\mathrm{mg} / \mathrm{L}$ & 13,815 & 12,240 & 9487 & 6607.5 & 35,400 & 27,450 & 3577 & 3255 \\
\hline $\begin{array}{l}\text { Suspended } \\
\text { matter }\end{array}$ & $\mathrm{mg} / \mathrm{L}$ & 12 & 9 & 25 & 35 & 61 & 8 & 112 & 34 \\
\hline $\mathrm{CCO}-\mathrm{Cr}$ & $\mathrm{mg} \mathrm{O}_{2} / \mathrm{L}$ & 458.28 & 127.53 & 699.48 & 69.56 & 892.44 & 266.66 & 651.2 & 150.72 \\
\hline $\mathrm{CBO}_{5}$ & $\mathrm{mg} \mathrm{O}_{2} / \mathrm{L}$ & & 5.66 & & 6.3 & & 6.91 & & 8.45 \\
\hline \multicolumn{10}{|l|}{ Metals } \\
\hline $\mathrm{Ca}$ & $\mathrm{mg} / \mathrm{L}$ & 25.163 & 17.876 & 40.459 & 34.257 & 107.954 & 60.909 & 24.63 & 19.916 \\
\hline $\mathrm{Fe}$ & $\mathrm{mg} / \mathrm{L}$ & 0.18 & 0.269 & 0.177 & 0.52 & 0.191 & 0.025 & 0.367 & 0.046 \\
\hline $\mathrm{Mg}$ & $\mathrm{mg} / \mathrm{L}$ & 142.942 & 70.994 & 96.943 & 52.713 & $>142$ & 97.146 & 100.3 & 70.883 \\
\hline Mn & $\mathrm{mg} / \mathrm{L}$ & 0.014 & 0.044 & 0.044 & 0.062 & 0.162 & 0.067 & 0.049 & 0.021 \\
\hline $\mathrm{Na}$ & $\mathrm{mg} / \mathrm{L}$ & 13990 & 12961 & $>13,990$ & 13702 & 1047 & 1012 & 1693 & 1415 \\
\hline $\mathrm{Zn}$ & $\mathrm{mg} / \mathrm{L}$ & 0.001 & 0.001 & 0.0014 & 0.0059 & 0.0015 & 0.0012 & 0 & 0 \\
\hline Co & $\mu \mathrm{g} / \mathrm{L}$ & 1.38 & 1.24 & 0.898 & 0.872 & 2.196 & 2.184 & 0.734 & 0.689 \\
\hline $\mathrm{Cr}$ & $\mu \mathrm{g} / \mathrm{L}$ & 0.989 & 0.881 & 0.95 & 0.907 & 1.741 & 1.691 & 0.945 & 0.918 \\
\hline $\mathrm{Pb}$ & $\mu \mathrm{g} / \mathrm{L}$ & 0.684 & 0.658 & 0.852 & 0.813 & 2.224 & 2.215 & 0.772 & 0.769 \\
\hline Cd & $\mu \mathrm{g} / \mathrm{L}$ & 0.013 & 0.011 & 0.046 & 0.039 & 0.064 & 0.061 & 0.005 & 0.004 \\
\hline
\end{tabular}


$\mathrm{CBO}_{5}$ one, which is more laborious requiring a five days' determination procedure. According to the chemical oxidation method (depending on the nature of the oxidant and the reactions involved) two types of parameters are determined: 1) COCMn-chemical oxygen consumption correlates best with $\mathrm{CBO}_{5}$, although by oxidation with $\mathrm{KMnO}_{4}$ in $\mathrm{H}_{2} \mathrm{SO}_{4}$ medium there are oxidized in addition about $30 \%$ - 35\% of non-biodegradable organic substances; 2) COCCr-chemical consumption of oxygen by oxidation with $\mathrm{K}_{2} \mathrm{Cr}_{2} \mathrm{O}_{7}$ in acid medium generally determines $60 \%-70 \%$ of organic substances, including heavy metals and non-biodegradable ones.

The COC-Mn parameter was within normal limits, excepting Caineni Lake where the oxygen consumption was slightly above the upper acceptable limit, probably to a high degree of hypertrophy caused by its relatively small size. It is a very good source of sapropelic mud, also suggesting a low redox potential.

However, according to the COC-Cr parameter, all analyzed lakes proved to have a high degree of hypertrophy, the highest values being registered for Caineni Lake (with a small surface and reduced capacity of self-purification) and Amara Lake-used for ecological breeding of juvenile fish; moreover, near Amara lake lies also a nursery using organic fertilizers which could also contribute to the local eutrophication.

The results of physico-chemical determinations made in the autumn of 2016 (indicated similar values to those from 2015, indicating a certain degree of stability of these aquatic ecosystems. So, for all four analyzed lakes, the chemical parameters from the salinity indicator group (chlorides, sulphates, calcium, magnesium, sodium, and filtration residue dried at $105^{\circ} \mathrm{C}$ ) recorded very high values, characteristic of salty, sulphate and magnesium rich waters. According to the literature, this salinity is a characteristic of these lakes and may be the consequence of the intake of salts from the underground waters (springs), of the inflow of near phreatic waters or of the salt deposited from the capillaries of the rocks washing [25] [26]. The concentration of the microelements with toxic potential (heavy metals: $\mathrm{Cd}, \mathrm{Cr}, \mathrm{Pb}, \mathrm{Co}$ ) in the water samples was far below the acceptable limits of the class I quality and no significant variations were observed between the two sampling campaigns. Higher values of these microelements were observed for the samples taken from Caineni Lake, but however, without exceeding the acceptable limits for class I quality.

In another study, the water and sapropelic muds from thirteen Ocna Sibiu salty lakes, the majority in the balnear perimeter were investigated for evaluate the physico-chemical, microbiological and enzymatically parameters of the lakes and the authors proved that the vast majority of the salty lakes in Ocna Sibiu are also eutrophic lakes and hypertrophic [27].

\subsection{Microbiological Characteristics of the Analyzed Plain Lakes}

The values obtained for the microorganisms involved in the cycle of the main biogenic elements (C, N, S) indicates a decrease of all analyzed bacterial populations in 2016 compared to the previous year by two or three logs (Figure 2). 
LAKE BALTA ALBA

口Medium 2015 पMedium 2016

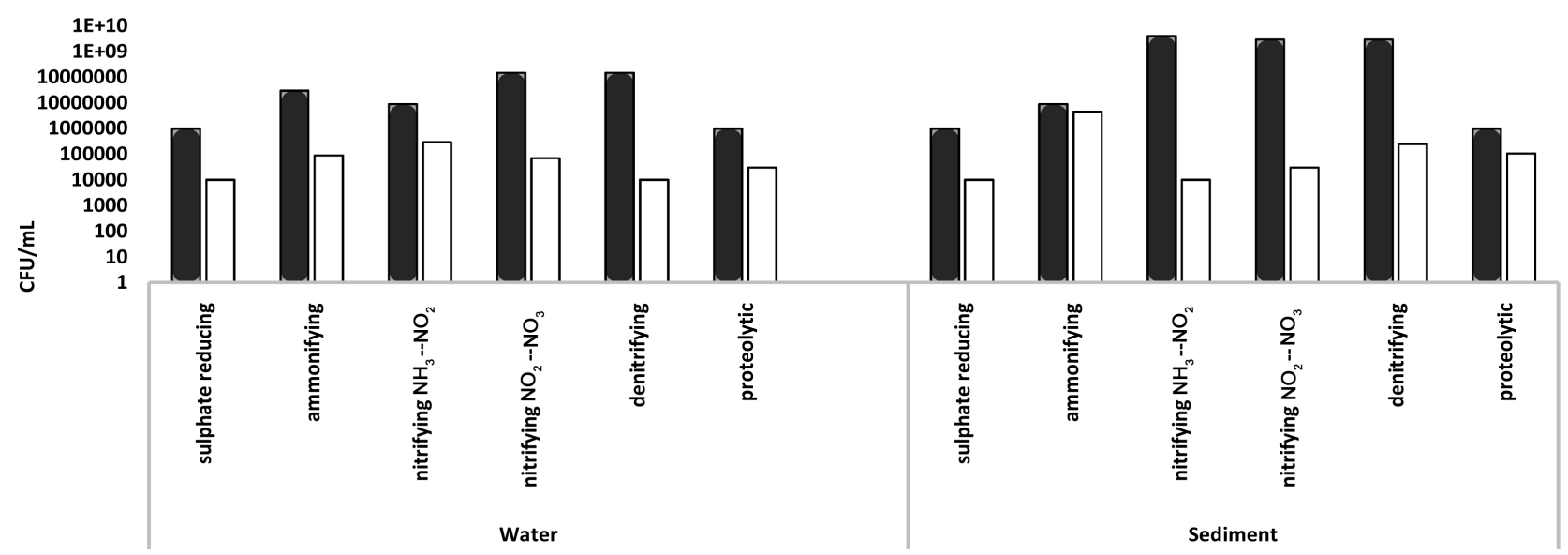

(a)

LAKE AMARA

$\square 2015 \square 2016$

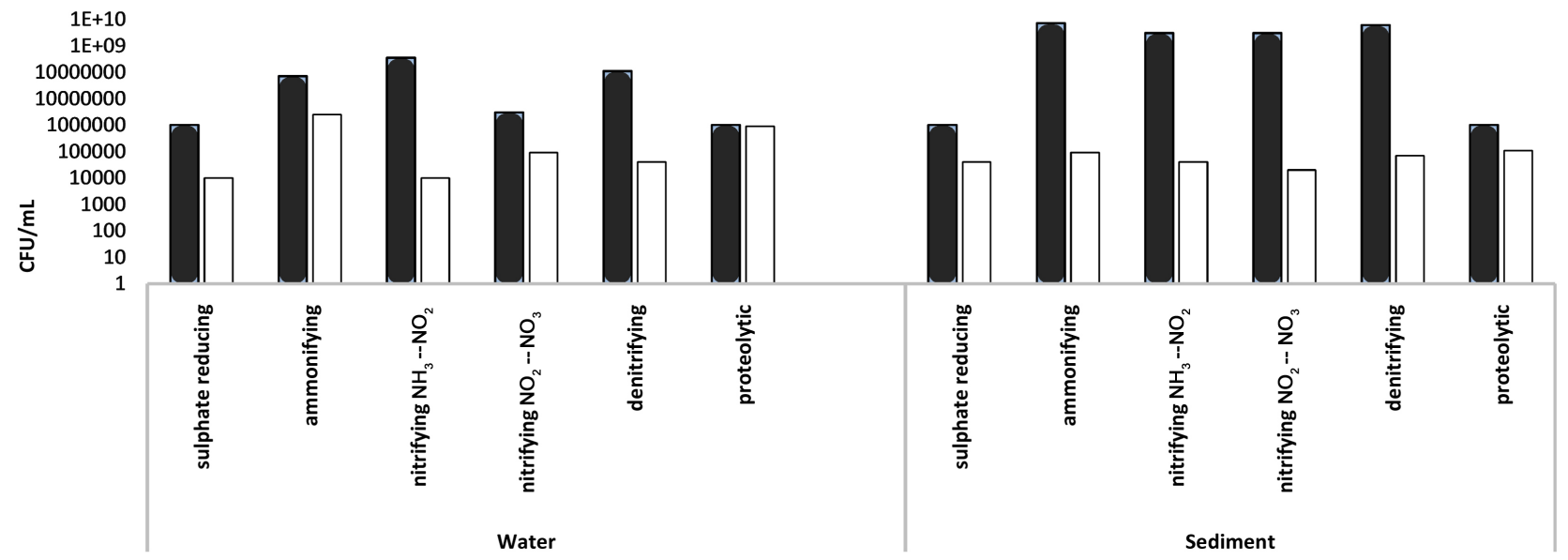

(b)

LAKE CAINEN I

प2015 प2016

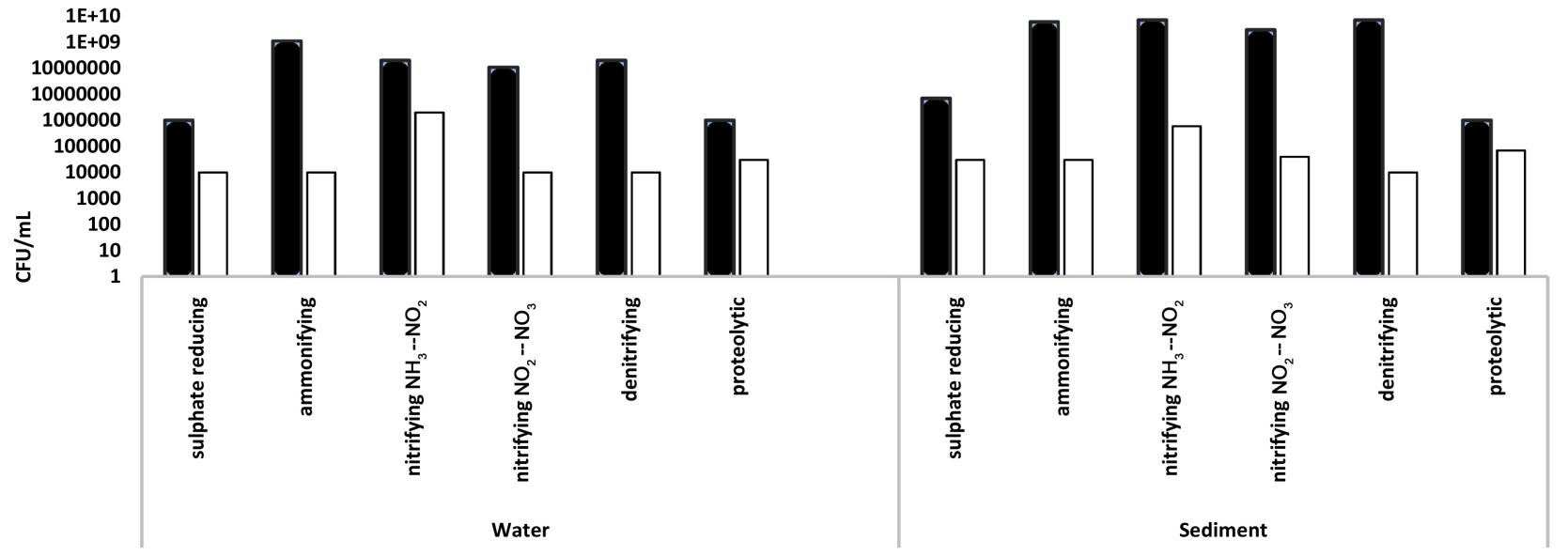

(c) 


\section{LAKE JIRLAU}

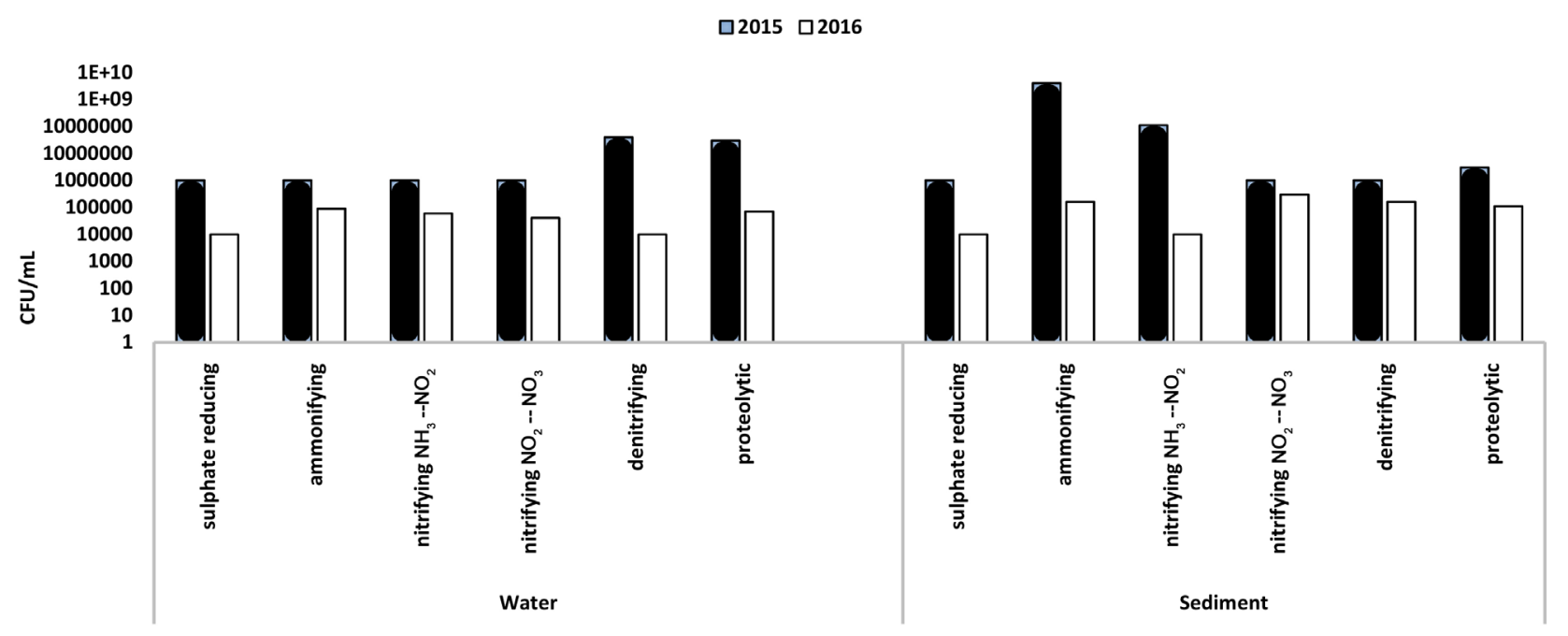

(c)

Figure 2. Most probable numbers (MPN) of different physiological groups of microorganisms involved in the organic matter biodegradation and biogenic elements cycles (carbon, nitrogen and sulfur) (proteolytic, ammonifying, nitrifying, denitrifying and sulphate reducing bacteria) in 2015 and 2016. (a) Lake Balta Alba, (b) Lake Amara, (c) lake Caineni, (d) lake Jirlau.

These results are in good agreement with those of total heterotrophic bacteria determinations (Figure 2) showing the same decreasing tendency of the total number of heterotrophic bacteria in 2016 as compared to 2015. The heterotrophic bacteria are involved in the decomposition and mineralization processes of dead organic matter in the soil and aquatic basins. To this, the organic matter from industrial-agricultural-domestic waters discharged into waters, responsible for the eutrophication phenomenon of waters is added. The heterotrophic bacteria are thus representing an indicator for the load of decomposing and mineralizing bacteria. The vulnerability of the situs Balta Alba-Amara-Jirlau-Lacul Sarat Caineni and of its aquatic ecosystems resides especially in the spillage of household waste, significant floods and consecutive natural modifications (Buzau river's flood) and artificial (due to fish farming activities) of the water composition [28]. In the aquatic ecosystems, the number of heterotrophic microorganisms has seasonal variations. Thus, during summer time, when the amount of oxygen drops below a certain limit, the rate of microbial biodegradation is diminished. In the autumn, temperature is the main factor determining the reduction in the intensity of oxidative processes of organic matter degradation. In spring, in most aquatic ecosystems, biodegradation reactions are low, but sometimes high values are recorded due to vegetal residues ungraded in autumn and resumed in the sediment during the spring flood. Generally, the intensity of aerobic decomposition processes of organic matter increases from spring to mid-autumn, then falls sharply [29]. The decomposing activity of heterotrophic microorganisms is of particular importance in all types of ecosystems, and even more in small surface and little deep lakes, where, without the intervention of microorganisms and their natural self-purification capacity, the large amounts of organic matter in- 
crease the risk of biological clogging of basins, with all the undesirable known effects. The decomposition and mineralization of a wide range of substrates by microorganisms results in the reintroduction of elements into bio-geo-chemical cycle, the end products or intermediates resulting from microbial decomposition/mineralization activity (in parallel with biosynthesis and microbial biomass growth reactions) reaching again to primary producers, in assimilate forms, which permit the restart/continuation of biogenic cycles [30]. Our results have shown that in the sampling campaign from 2015, the values recorded for the group of aerobic heterotrophic bacteria indicated a high contamination with a biodegradable organic substance, corresponding to the 4th and 5th grade class of contamination (Figure 3), indicating an optimal heterotrophic potential for organic matter conversion, but also a high organic pollution.

The highest density of aerobic heterotroph microorganisms was registered in Lakes Amara and Jirlau. The high degree of organic pollution registered in 2015 was also demonstrated by the high counts of sulphate-reducing bacteria. In nature, all microbiological processes involved in S cycle are closely correlated with the production and. The release of $S$ from proteins during decomposition of organic matter occurs after the death of organisms, and the microbiological decomposition of their residues till complete mineralization is accompanied by the production of $\mathrm{H}_{2} \mathrm{~S}$ (in anaerobiosis) and sulphates (in aerobiosis), partially usable by plants in the process of assimilation reduction of sulphates. The number of sulphate-reducers is therefore an indicator of organic pollution, being present in large numbers at the surface of sediments in mesotrophic and eutrophic waters and in small number in oligotrophic waters. The massive development of sulphate-reducers is associated with increased mortality of aquatic organisms as a result of $\mathrm{H}_{2} \mathrm{~S}$ accumulation, toxic to most organisms. Also, $\mathrm{H}_{2} \mathrm{~S}$ precipitates soluble Fe from waters and soil, resulting the FeS which can be seen as a black

\section{BACTERIOLOGICAL INDICATORS}

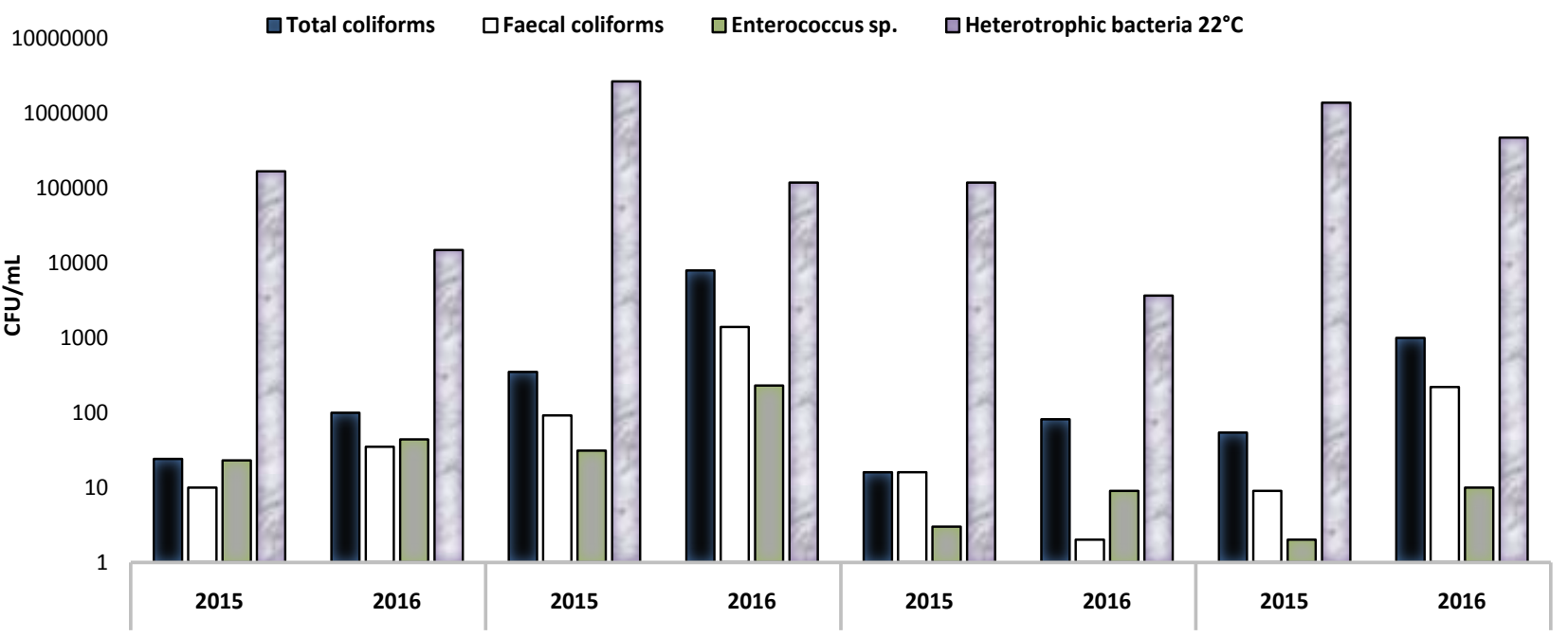

Figure 3. Values of bacteriological indicators of water quality. ${ }^{\star} \mathrm{CFU}=$ colony forming units. 
layer at the surface of sediments and sludge. In 2016, for all monitored lakes, a slight decrease of aerobic heterotrophic bacteria was observed compared to 2015 . Thus, for the Jirlau and Caineni lakes, the values recorded for this indicator showed a moderate contamination with readily biodegradable organic substances. Instead, for the Balta Alba and Amara lakes, a critical level of pollution with biodegradable organic substance was still observed. We have assessed the physiological groups of microorganisms involved in different steps of the nitrogen cycle in nature, respectively: 1) biological fixation of $\mathrm{N}_{2}, 2$ ) amonification, 3) nitrification, and 4) denitrification. After decomposition of the proteic organic matter by proteolytic microorganisms, the ammonifiers provide further degradation and conversion of the compounds obtained from the previous step to $\mathrm{NH}_{3}$. The $\mathrm{NH}_{3}$ is partially released into the atmosphere and the rest of it is temporarily adsorbed on clay-humus complexes or converted under aerobic conditions to $\mathrm{NH}^{4+}$, then oxidized through the nitration process to nitrites and nitrates, which assimilable by plants and the most accessible form for most microorganisms. Nitrifying bacteria are present in soil, aquatic basins, sewage treatment systems and composts. Maximum soil density is reached in the upper layers (up to $10 \mathrm{~cm}$ ), and in aquatic basins at the interface between water and sediment, because it is an aerobic process. In parallel with the nitrification, through denitrification the nitrates and nitrites are reduces to nitric oxide- $\mathrm{NO}$ or nitrous oxide $-\mathrm{N}_{2} \mathrm{O}$ and further to $\mathrm{N}_{2}$ that is released in the atmosphere. Denitrification is a facultative anaerobic process and represents a way of $\mathrm{N}$ loosing from ecosystems and reducing of soil fertility. Denitrifying agents are abundant in aquatic sediments, rich in organic matter, the process being favored in anaerobic conditions. The number of denitrifying bacteria was generally high and, as expected, slightly higher in aquatic sediments, than in water samples, the results of the microbiological analysis correlating well with the results of the chemical determinations, which showed low concentrations of nitrates in all samples, while the total nitrogen was higher.

Bryanskaya and colab., studied the structure of microbial communities of saline lakes of the Novosibirsk region and the effect of physical-chemical parameters of waters on microbial communities of that lakes. Many diverse microbial communities were found, (Bacteria, Archaea, Algae, and Cyanobacteria), nonuniformly distributed, a direct correlation between microbial abundance and water salinity being observed [31].

Some of the lakes sampled in the present study (Amara and Balta Albă) were also investigated by other authors, but focusing on the detection of halophilic microorganisms (bacteria and archaea) and phyto- and zooplankton species in relation with physical-chemical parameters, and also on the evaluation of halobacterial extracellular hydrolytic activities. However, our study complements these data with results regarding the anthropogenic pollution [32] [33] [34]. The pollution of monitored lakes with potentially pathogenic microorganisms was evaluated through the quantitative assay of the number of total coliform bacte- 
ria, fecal coliforms and enterococci (Figure 2). Total coliforms group indicates the general pollution with pathogenic microorganisms originating from the anthropic systems, as well as from the natural ecosystems (soil, plants, and animals), the fecal coliforms are specific indicators of recent fecaloid pollution with human and animal origin and enterococci-an indicator that confirms the fecal origin of chronic water pollution. For water samples taken in the 2015 campaign, the values obtained for total coliform bacteria indicated a moderate bacteriological contamination level with a tendency towards critical values (Amara Lake). In 2016 the values for this parameter varied between a moderate level of contamination (Lake Caineni) and a high level of contamination (Amara and Jirlau lakes). The coliform group is widespread in nature and is not considered to be of direct epidemiological importance for water analysis. This group of bacteria indicates the general pollution with potentially pathogenic microorganisms originating from anthropogenic systems (household wastewater, livestock), but also with allohtonic species originating from natural ecosystems (soil, plants, animals). In 2015, the values obtained for fecal coliform bacteria-a specific indicator of fecaloid pollution of human and animal origin-indicated a moderate to critical level of bacteriological contamination. In 2016, for the Jirlau and Amara lakes, there was a slight increase in the values of this indicator, the level of bacteriological pollution ranging between moderate and excessive (Lake Amara). In both sampling campaigns, enterococcal values indicated a level of contamination ranging from critical to excessive. The bacterial species/members of this group are eliminated in the environment from the intestinal tract of human and animals, being of fecal origin. Along with fecal coliforms, and due to their particular resistance to physical, chemical and biological agents, these species have an important sanitary value as indicators for fecal water pollution. In the area of the monitored lakes, this type of pollution can indicate the existence of some local sources of pollution (domestic waste water evacuation, wastewater from livestock farmers, etc.) and/or diffuse sources of pollution (infiltration from agricultural land, pastures, etc.). Taking into account the generally high recorded values for total coliform bacteria, thermotolerant/fecal coliform bacteria, enterococci obtained for the monitored lakes, it can be concluded that these lakes are affected by continuous contamination, both indicators of recent and chronic pollution being recorded at high values. As a result, it is necessary to identify the sources of pollution and to apply appropriate management to minimize the negative impact on water quality. The results from 2015 indicated levels admitted by current standards, yet higher than those reported by other authors [35]. Of all the samples, the total number of coliform bacteria and fecal coliforms only in the Amara Lake water exceeded the maximum admissible levels [36] [37], indicating a high level of domestic fecaloid pollution; the lake being near the village of Amara, a possible explanation for this high bacterial load would consist of sporadic discharge of household waste, but also the contamination with organic fertilizers used for the surrounding agricultural lands (anthropogenic influence). 
Instead, the results for the samples harvested in 2016 indicate an increase of domestic fecaloid pollution, a possible explanation being household waste discharges as well as the infiltration/fertilization of farmland with manure, aspects that could explain the eutrophication of the lakes from the respective area (Balta Alba, Amara, Jirlau).

\section{Conclusion}

The physico-chemical and microbiological assessment of the impact of organic pollution on the aquatic ecosystem of the four lakes located in the protected sites ROSCI0005 and ROSPA0004 included in the Natura 2000 network demonstrated a high degree of hypertrophy in the investigated plain lakes that could represent a positive premise for the productivity of these ecosystems, but also an alarm signal for excessive organic pollution, with risk of high oxygen demand in water and a dangerous decrease of the redox potential which can affect the fish and other life forms. The water $\mathrm{pH}$ in the analysed lakes ranged from 7.56 to 8.93, these values close or above the upper normal limit of 8.5 , being correlated with a high salinity characteristic of chlorinated, sulphated, sodium and magnesium waters. The COC values revealed a high degree of hypertrophy, which could be attributed to different reasons, such as reduced surface area, ecological pisciculture, and input of soil fertilizers by leaching process. However, the similar values recorded for the physico-chemical parameters in the two consecutive years indicate a certain degree of stability of the investigated aquatic ecosystems. The microbiological analyses revealed a high contamination with biodegradable organic substances, corresponding to the 4th and 5 th grade class of contamination in 2015. This level was maintained in 2016 for two lakes, while for the other two a decrease from high to a moderate organic pollution was recorded. The levels of bacteriological indicators of water quality in the monitored lakes indicate that these waters are also affected by both recent and chronic faecal pollution. Consequently, it is necessary to identify the sources of pollution and apply an appropriate management to minimize the negative impact on the balance of the respective ecosystems (water quality, biotic components) in order to maintain the health of the surrounding human communities and of the environment, allowing at the same time a sustainable use of the local resources.

\section{Acknowledgements}

The financial support of ERANET-0296-JPI-EC-AMR-AWARE-WWTP and of UEFISCDI 11PED/2017 code 32838 is gratefully acknowledged.

\section{References}

[1] Herlea, V., Lazar, V., Canja, D., Ciolac-Russu, A. and Popescu, V. (1995) The Characterization of Several Aspects of the River's Prahova Microbiota Diversity, with Implications in Biodegradation of Released Pollutants (1994-1995). Annals of Bucharest University, XLIV, 77-88. 
[2] (2011) Links between the Water Framework Directive (WFD 2000/60/EC) and Nature Directives (Birds Directive 2009/147/EC and Habitats Directive 92/43/EEC) Frequently Asked Questions.

http://ec.europa.eu/environment/nature/natura2000/management/docs/FAQ-WFD \%20final.pdf

[3] Ball, P. (2000) Life's Matrix: A Biography of Water. Farrar Straus and Giroux, New York.

[4] Dodds, W.K. (2002) Freshwater Ecology, Concepts and Environmental Applications. Academic Press, San Diego.

[5] (2005) Penkala Bt., Budapest. http://www.ecology.kee.hu

[6] https://dge.carnegiescience.edu/SCOPE/SCOPE_12/SCOPE_12_3.7_chapter13_275 -294.pdf

[7] Berhe, A.A., Carpenter, E., Codispoti, L., Izac, A.M., Lemoalle, J., Luizao, F., Scholes, M., Treguer, P. and Ward, B. (2005) Ecosystems and Human Well-Being: Current State and Trends. In: Etchevers, J. and Tiessen, H., Eds., Chapter $12 \mathrm{Nu}$ trient Cycling.

[8] Lazar, V., Marutescu, L. and Chifiriuc, M.C. (2017) General Microbiology. University of Buch. Publs. House.

[9] Moss, B. (2008) Water Pollution by Agriculture. Philosophical Transactions of the Royal Society B. Biological Sciences, 363. https://doi.org/10.1098/rstb.2007.2176

[10] Panus, E., Chifiriuc, C., Bucur, M., Cernat, R., Mitache, M., Nedelcu, D., Bleotu, C., Valeanu, D. and Lazar, V. (2008) Virulence, Pathogenicity, Antibiotic Resistence and Plasmid Profile of Escherichia coli Strains Isolated from Drinking and Recreational Waters. Romanian Biotehnological Letters, 13, 3695-3700.

[11] Dubey, S.K. (2005) Microbial Ecology of Methane Emission in Rice Agroecosystem: A Review Centre of Advanced Study, Department of Botany, Banaras Hindu University, Varanasi, India. Applied Ecology and Environmental Research, 3, 1-27.

[12] http://www.int-res.com/articles/theme/m396_ThemeSection.pdf

[13] Kumar, B.L. and Gopal, D.V.R.S. (2015) Effective Role of Indigenous Microorganisms for Sustainable Environment. 3 Biotech, 5, 867-876.

https://doi.org/10.1007/s13205-015-0293-6

[14] Rodina, A.G., Colwell, R.R. and Zambruski, M.S. (1972) Methods in Aquatic Microbiology. University Park Press, Baltimore.

http://trove.nla.gov.au/version/25363288

[15] Lazar, V., Herlea, V., Cernat, R., Balotescu, C., Bulai, D. and Moraru, A. (2004) General Microbiology (Manual of Laboratory Techniques). Univ. of Buch. Publs. House.

[16] Lazar, V., Chifiriuc, M.C., Curutiu, C., Mitache, M.M., Marinescu, F., Croitoru, C., Mateescu, L. and Marutescu, L. (2015) Methods and Standards Formicrobiological Control Laboratories. Univ. of Buch. Publs. House.

[17] Kavka, G.G., Kasimir, G.D. and Farnleitner, A.H. (2006) Microbiological Water Quality of the River Danube ( $\mathrm{km} 2581$ - km 15): Longitudinal Variation of Pollution as Determined by Standard Parameters. 36th International Conference of IAD, Austrian Committee Danube Research/IAD, Vienna, Proceedings, 415-421.

[18] https://search.avast.com/AV772/search/web?q=ROSPA0004

[19] http://www.mmediu.ro/img/attachment/33/arii-naturale-protejate-547857c5e7545. pdf

[20] http://pasaridinromania.sor.ro/Balta-Alba-Amara-Jirlau 
[21] http://www.iucnredlist.org/details/22692543/0

[22] Bhat, S.A., Meraj, G., Yaseen, S. and Pandit, A.K. (2014) Statistical Assessment of Water Quality Parametres for Pollution Source Identification in Sukhnag Stream: An Inflow Stream of Lake Wular (Ramsar Site), Kashmir Himalaya. Journal of Ecosystems, 2014, Article ID: 898054.

[23] Chapra, S.C., Dove, A. and Warren, G.J. (2012) Long-Term Trends of Great Lakes Major Ion Chemistry. Journal of Great Lakes Research, 38, 550-560. https://doi.org/10.1016/j.jglr.2012.06.010

[24] Grochowska, J. and Tandyrak, R. (2009) The Influence of the Use of Land on the Content of Calcium, Magnesium, Iron and Manganese in Water Exemplified in Three Lakes in Olsztyn Vincinity. Limnological Review, 9, 9-16.

[25] Sheikh, J.A., Jeelam, Gh., Gavali, R.S. and Shah, R.A. (2014) Weathering and Antrophogenic Influences on the Water and Sediment Chemistry of Wular Lake, Kashmir Himalaya. Environmental Earth Sciences, 71, 2837-2846. https://doi.org/10.1007/s12665-013-2661-Z

[26] Marlow, R.L., Willey, P.H., Wenberg, R.D., Rice, J., Twitty, W.K., Ross, E. and Backlund, V. (2001) Chapter 14, Water Management (Drainage). In: Engineering Field Handbook, Part 650, 210-VI-NEH.

[27] Poplăcean, M. and Oprean, L. (2009) Microbiological and Enzymological Characterization of Water and Sapropelic Muds in the Lakes of Ocna Sibiu. Acta Universitatis Cibiniensis Series E: Food Technology, 13, 49-56.

[28] Munteanu, C. (2012) Nămolul Therapeutic. Ed. Balneară, Bucharest, Romania, 43-106.

[29] http://biodiversitate.mmediu.ro/rio/natura2000/view?doc_id=ROSCI0005

[30] Ionică, D. and Simon-Gruița, A. (1995) New Methodological Approaches in Microbial Ecology on Quantification of Microbial Communities Biomass. Studies and Research of Biology. Animal Biology Series, 47, 141-144.

[31] Bryanskaya, A.V., Malup, T.K., Lazareva, E.V., Taran, O.P., Rozanov, A.S., Efimov, V.M. and Peltek, S.E. (2016) The Role of Environmental Factors for the Composition of Microbial Communities of Saline Lakes in the Novosibirsk Region (Russia). BMC Microbiology, 16, 4. https://doi.org/10.1186/s12866-015-0618-y

[32] Moldoveanu, M., Florescu, L., Parpală, L., Cojoc, R. and Enache, M. (2015) Romanian Salt Lakes: Some Physical-Chemical Features and Composition of Biological Communities. Oltenia. Studii şi comunicări. Ştiinţele Naturii. Tom, 31, 205-212.

[33] Păceşilă, I., Cojoc, R. and Enache, M. (2014) Evaluation of Halobacterial Extracellular Hydrolytic Activities in Several Natural Saline and Hypersaline Lakes from Romania. British Biotechnology Journal, 4, 541-550. http://www.sciencedomain.org/ https://doi.org/10.9734/BBJ/2014/10239

[34] Panus, E., Chifiriuc, M.C., Bleotu, C., Mitache, M. and Rosoiu, N. (2012) Impact of Different Environmental Parameters upon the Susceptibility to Heavy Metals Salts in Escherichia coli Aquatic Strains. Letters in Applied NanoBioScience, 2, 50-55.

[35] Zarnea, G. (1994) Treatise of General Microbiology; Vol. V, Microbial Ecology. University of Bucharest. Publs. House.

[36] Zmyslowska, I., Lewandowska, D. and Guziur, J. (2000) Microbiological Evaluation of Pond Water during carp and ide Rearing. Archives of Polish Fisheries, 8, 75-93.

[37] http://www.rowater.ro/dacrisuri/Documente\%20Repository/Legislatie/gospodarirea \%20apelor/ORD.\%20161_16.02.2006.pdf 